\title{
INTERNALISASI NILAI RELIGIUS PADA RENCANA PELAKSANAAN PEMBELAJARAN (RPP) MUATAN LOKAL BAHASA JAWA DI LEMBAGA PENDIDIKAN ISLAM
}

\author{
INTERNALIZATION OF RELIGIOUS VALUES IN LESSON PLAN (RENCANA \\ PELAKSANAAN PEMBELAJARAN-RPP) OF LOCAL CURRICULUM OF JAVANESE \\ LANGUAGE IN ISLAMIC EDUCATIONAL INSTITUTIONS
}

Fatia Azzahrah, Budhi Setiawan, Supana

Pendidikan Bahasa Jawa,Universitas Sebelas Maret Surakarta

Jl. Ir Sutami 36 A Jebres, Surakarta, Jawa Tengah

email: fatiaazzahrah@gmail.com

Naskah Diterima: 10 September 2018; Direvisi: 08 Oktober 2018; Disetujui: 01 Desember 2018

\begin{abstract}
The loss of character students is currently a problem in educational institutions. Madrasah as Islamic educational institutions become media as well as channel the values of character education through learning activities. Javanese language learning contains a variety of material that is rich in character values. The purpose of this study, to analyze the integration of religious values in the Learning Implementation Plan (RPP) of Javanese Language. Javanese language learning planning and information from resource persons are used as research data, while data sources are in the form of Javanese language RPP local content documents and class X Javanese teacher informants. The results of the study show that the lesson plans developed by teachers contain religious values, internalization of religious values in the plan The implementation of Javanese language learning is included in the initial activities, precisely the motivation and subject matter section by giving verses of the Koran or Hadith. Internalization of religious values in the form of giving verses of the Koran or Hadith in the Learning Implementation Plan (RPP) can later be implemented in learning activities, so that these subjects can serve as contributions to the planting of religious values to students.
\end{abstract}

Keywords: Internalisation religious values; Islamic education institutions; Javanese language; Learning Implementation Plans; Madrasah

\begin{abstract}
Abstrak
Hilangnya karakter peserta didik saat ini menjadi permasalahan di lembaga pendidikan. Madrasah sebagai lembaga pendidikan Islam menjadi media sekaligus penyalur nilai-nilai pendidikan karakter melalui kegiatan pembelajaran. Pembelajaran bahasa Jawa memuat berbagai materi yang kaya akan nilai karakter. Tujuan dari penelitian ini, menganalisis pengintegrasian nilai religius dalam Rencana Pelaksanaan Pembelajaran (RPP) Bahasa Jawa. Perencanaan Pembelajaran bahasa Jawa dan informasi dari narasumber digunakan sebagai data penelitian, sedangkan sumber data berupa dokumen RPP muatan lokal Bahasa Jawa kelas X dan informan guru bahasa Jawa kelas X. Hasil penelitian menunjukkan bahwa RPP yang dikembangkan oleh guru mengandung nilai religius, internalisasi nilai religius dalam Rencana Pelaksanaan Pembelajaran bahasa Jawa dimasukan pada kegiatan awal tepatnya bagian motivasi dan materi pelajaran dengan memberikan ayat Alquran atau hadis. Internalisasi nilai religius berupa pemberian ayat Alquran atau hadis di dalam Rencana Pelaksanaan Pembelajaran (RPP) nantinya dapat diimplementasikan dalam kegiatan pembelajaran, sehingga mata pelajaran tersebut dapat berfungsi sebagai konstribusi penanaman nilai religius kepada peserta didik.
\end{abstract}

Kata kunci: Nilai religius; Pendidikan Islam; Mulok Bahasa Jawa; Rencana Pelaksanaan Pembelajaran 


\section{PENDAHULUAN}

Permasalahan krisis moral sedang dialami oleh negeri ini. Presiden Joko Widodo mengakui bahwa pendidikan budi pekerti masih menjadi pekerjaan rumah yang besar di Tanah Air. ${ }^{1}$ Munculnya berbagai gejala mengenai rusaknya karakter peserta didik seperti tidak memiliki sopan santun maupun tata krama dan subasita, mudahnya mengucap kata-kata kotor tanpa adanya perasaan canggung dalam mengucap, tidak tahu bagaimana cara berbicara dengan orang yang lebih tua (orang tua dan guru), cara berbicara yang tidak mencerminkan sebagai siswa generasi muda masyarakat suku Jawa yang penuh dengan kehalusan, sopan-santun, etika serta keramahan.

Seperti berita di Kendal mengenai tindakan siswa yang berlaku tidak sopan terhadap gurunya, yang viral melalui video berdurasi 24 detik. Di dalam video tersebut siswa mem-bully gurunya, kakinya menendang-nendang sampai salah satu dari sepatunya terlepas dari kaki. Pihak sekolah dan guru yang bersangkutan menyatakan bahwa rekaman di video yang viral hanya guyonan, bukan kekerasan, atau pengeroyokan. Namun pihak sekolah mengakui guyonan atau candaan sejumlah siswa terhadap gurunya merupakan tindakan atau perbuatan yang kelewat batas kesopanan/etika sosial. $^{2}$

Pembentukan nilai-nilai karakter pada masa remaja sangat penting dalam upaya menangkal pengaruh negatif yang dapat merusak karakter remaja sebagai generasi bangsa. Perkembangan karakter positif yang terhambat akan berakibat pada terjadinya kenakalan yang berujung pada tindak kriminal di kalangan pelajar. ${ }^{3}$ Penanaman pendidikan karakter dilembaga pendidikan formal menjadi salah satu solusi untuk membenahi moral generasi muda khususnya siswa.

${ }^{1}$ Purwadi. (2018). Siswa Bunuh Guru, Jokowi: Ada Apa ini? Kenapa ini Terjadi?. Republika.co.id. Diakses 20 Apri 2018

${ }^{2}$ https://news.detik.com/berita/4299012/viralguru-di-bully-murid-sekolah-akan-perkuat-pendidikankarakter.

${ }^{3}$ Muzayanah, Umi. (2014). Strategi Pendidikan Karakter Pada Madrasah Tsanawiyah Muhammadiyah 01 Purbalingga, Jawa Tengah. Jurnal Edukasi, Vol. 12, No. 3., h 339-340.
Madrasah merupakan satu lembaga formal yang kental sekali akan nilai-nilai keislaman dan identik dengan hal keagamaan. Tugas dari setiap lembaga pendidikan yaitu memberikan pelajaran, pengarahan terhadap peserta didik dan menghasilkan generasi muda yang berkarakter, baik memiliki perilaku yang mulia, akhlak yang baik serta memiliki kecerdasan yang luar biasa. Idealnya, lembaga pendidikan di samping menjadi tempat mentransfer ilmu, juga mampu menjadi tempat membentuk karakter dan moral peserta didiknya. ${ }^{4}$ Keterlaksanaan pendidikan karakter di sekolah merupakan tanggungjawab semua mata pelajaran yang diajarkan di sekolah. ${ }^{5}$

Implementasi pendidikan karakter dapat diintegrasikan pada mata pelajaran muatan lokal seperti bahasa Jawa. Pelajaran bahasa Jawa menjadi salah satu wadah yang dapat digunakan sebagai media penanaman nilai. Penanaman nilai dapat dilakukan melalui materi pelajaran yang mengintegrasikan budaya lokal, seperti dalam materi kebudayaan mengenai adat begalan yang ada di Banyumas bahwa "the role of religiosity in Begalan Banyumasan as a Character education in schools had an important role from the order of events, speech, and equipment brought in Begalan had each meaning or religious values. the Brenang kepang equipment contained many value of educational charachter that is relevan to the curiculum and learning prosess in schools, especially in high school level trough the high school level, the value of religiosity charachter education espespecially in the traditional ceremony begalan banyumas can be used as a source and tool in teaching and learning activities. " 6

${ }^{4}$ Faiqoh. (2015). Model Pembentukan Karakter Religius Santri Tahfidz Al-Quran Di Pondok Pesantren Mathali'ul Huda Pusat Kajen Pati. Edukasi: Jurnal Penelitian Pendidikan Agama dan Keagamaan, Vol 13, No. 3, h 350.

${ }^{5}$ Ma'rifataini, Lisa'diyah . (2017). Best ractice Pendidikan Agama Isam (PAI) Di Sekolah (SMA/SMK). Edukasi: Jurnal Penelitian Pendidikan Agama dan Keagamaan. Vol 15, No. 1, h 35.

${ }^{6}$ Saddhono, Kundharu dan Kurniawan, alva. (2017). Islamic Religious in Traditional ceremony of Begalan Banyumasan as Educational Character for Student at Senior High Schools In Central Java. Internasional Journal of Islamic and Civivilizationnal Studies, 4(1), hal. 71-77. 
Budaya Jawa digunakan masyarakat Jawa sebagai pedoman dalam berperilaku dan bersikap dalam kehidupan sehari-hari. Bermacam-macam keunikan budaya yang dimiliki oleh daerah seperti nyanyian (tembang), aksara, kesenian, bahasa, bangunan, kegiatan keagamaan dan yang lainnya. Nilai filsafat luhur yang terdapat dalam budaya Jawa merupakan warisan yang dapat digunakan oleh masyarakat sebagai pelajaran dan pengalaman hidup. Seperti pernyataan berikut bahwa "local wisdome is a system of local knowledge held by the community based on the experience and guidance of theire ancestor to deal with local situations and conditions summarised in verbal and non-verbal expression to obtain the traquility of living together, humanism and dignity". 7

Selanjutnya juga diungkapkan bahwa budaya Jawa memiliki banyak nilai-nilai luhur yang dapat dijadikan sebagai pedoman, yaitu "Kraton Surakarta adalah bangunan budaya yang mengandung nilai sejarah dan merupakan anugrah Allah (sebagai) pedoman hidup (tuntunan agesang), tindak utama (luhuring budi), tatakrama, kasusilaan, tata bahasa, serta manunggaling kawula gusti atau tuntunan moralitas menuju darma, kebaikan, hayu-hayem-hayon (kedamaian, keselamatan, dan perlindungan)". 8

Pendapat selanjutnya bahwa budaya Jawa dapat dijadikan oleh masyarakat sebagai pedoman dalam kehidupannya, yaitu "Melalui syair dalam tembang, nilai-nilai religius Islam dan pitutur bijak disampaikan penuh makna. Nilai religius Islam dan pitutur bijak tersebut menjadi pegangan dan bagian hidup yang tak terpisahkan dari masyarakat Jawa dalam menjalani kehidupan beragama dan berbangsa". 9

${ }^{7}$ Saddono, Kundaru dan Pramestuti, Dewi. (2018). Sekar Macapat Pocung: Study Of Religius Values Based On Javanese Local Wisdom. Jurnal ElHarakah, 20(1), hal. 20.

${ }^{8}$ Nitinagoro, Hamaminata dan Wartiningtyas. (2009). Keramat Kyai Yosodipuro. Semarang: Intemedia Paramadina.

${ }^{9}$ Saddhono, Kundharu dan Pramestuti, Dewi. (2018). Sekar Macapat Pocung: Study Of Religius Values Based On Javanese Local Wisdom. Jurnal ElHarakah, 20(1), hal. 15-32.
Pengimplementasian nilai-nilai karakter budaya Jawa dalam pembelajaran dapat terlaksana dengan baik apabila perencanaan yang dilaksanakan juga baik dan matang. Perencanaan pembelajaran merupakan rancangan kegiatan yang akan dilaksnaakan dalam suatu pembelajaran baik satu pertemuan atau lebih, sehingga apa yang dilaksnakan dalam pembelajaran merupakan implementasi dari rencana pembelajaran tersebut.

Penelitian mengenai pendidikan karakter dalam mata pelajaran bahasa Jawa sebelumnya penah dilakukan oleh Kartika Sari, Suwandi, dan Supana (2018). Penelitian tersebut mengenai nilai pendidikan karakter dalam suatu materi pembelajaran bahasa Jawa (Aksara Jawa) yang dianalisis secara semiotik. Penelitiannya mengahasilkan temuan bahwa makna semiotik legenda aksara Jawa mengandung nilai pendidikan karakter religius, kerja keras, demokratis, rasa ingin tahu, menghargai prestasi dan lain-lain yang mana nilai pendidikan karakter itu relevan dengan nilai-nilai pendidikan karakter yang ditetapkan oleh Kementrian Pendidikan Nasional sehingga dapat dimanfaatkan sebagai materi kontekstual berbasis pendidikan karakter pada proses pembelajaran. ${ }^{10}$

Penelitian sebelumnya memiliki kemiripan dengan penelitian yang dilakukan oleh peneliti, dimana membahas mengenai nilai pendidikan karakter. Akan tetapi, penelitian terdahulu lebih terfokus pada nilai yang terkandung pada materi pembelajarannya, sedangkan penelitian ini terfokus pada perencanaan pembelajarannya.

Banyaknya pitutur luhur yang terkandung di dalam budaya Jawa, menjadikan penelitian ini perlu dilakukan. Penyusunan perencanaan pembelajaran digunakan sebagai sasaran penelitian untuk mengetahui bagaimanakah pengintegrasian nilai karakter di dalam perencanaan pembelajaran bahasa Jawa. Selain itu, bagaimana pengintegrasian nilai pendidikan karakter religius dalam perencanaan pembelajaran muatan lokal bahasa Jawa.

${ }^{10}$ Kartika Sari, Fitrina., Suwandi, Sarwiji., dan Supana. (2018). Caracter Education Values in Semiotic Meaning of Story of Javanese Script. Jurnal Komposisi. 19(1), hal. 48. 


\section{Lembaga Pendidikan Islam}

Madrasah merupakan salah satu lembaga pendidikan yang mengedepankan nila-nilai agama khususnya Islam. Nilai-nilai dasar yang digunakan untuk menejemen madrasah juga tidak jauh dari syariat agama. Visi dan misi madrasah selain menghasilkan lulusan yang cerdas mampu bersaing di dunia kerja, madrasah juga memfokuskan pada lulusan yang memiliki akhlak budi pekerti yang baik.

Kegiatan yang biasa dilaksanakan di madrasah masih berkaitan dengan kegiatan keagamaan. Beberapa kegiatan yang menjadi kebiasaan di madrasah yaitu tadarus pagi (sebagai kegiatan literasi), menyanyikan lagu wajib, solat dhuha, solat zuhur berjamaah, kegiatan tahfidz juz amma dan lain-lain. Kegiatan tersebut tidak mutlak seperti itu, setiap madrasah memiliki kegiatan yang berbeda-beda.

Nilai-nilai keagamaan merupakan pondasi sikap yang diberikan kepada diri peserta didik. Kentalnya nilai-nilai keagamaan di madrasah membuat madrasah menjadi agak berbeda dengan sekolah pada umumnya pada sifat kereligiositasannya.

\section{Integrasi Nilai pendidikan Karakter Religius}

Integrasi pendidikan karakter merupakan langkah untuk internalisasi nilai-nilai kepada peserta didik. ${ }^{11}$ Proses pembelajaran adalah wahana yang tepat untuk melakukan rekayasa mental agar terjadi internalisasi nilai-nilai pada diri peserta didik. ${ }^{12}$

Pembentukan karakter melibatkan intelegensi quetion (IQ), Emotional quetion $(E Q)$, creativity question $(C Q)$, yang tertuju pada pembentukan spiritual quetion $(S Q) .^{13}$ Pada setiap mata pelajaran guru perlu memiliki misi untuk menyisipkan atau menyampaikan pesan-pesan moral berdasar pada nilai-nilai karakter. Nilai-nilai tersebut dapat disampaikan

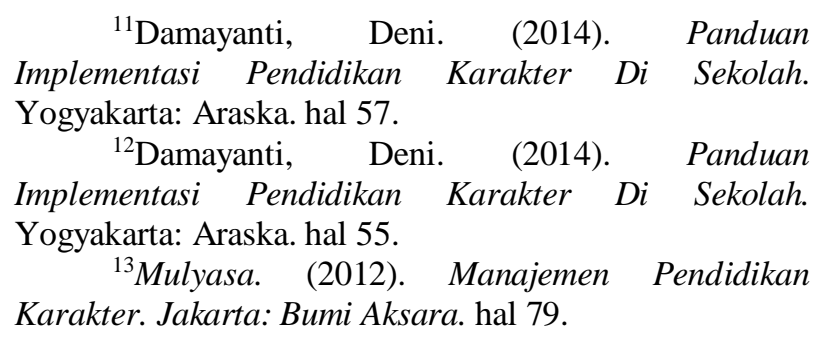

secara intelektualistik pada saat mengawali atau mengakhiri proses pembelajaran selain itu, dapat disisipkan di sela-sela penyampaian materi ajar. Semua nilai pendidikan karakter dapat diinternalisasikan ke dalam pembelajaran, hanya saja harus disesuaikan dengan pokok bahasan materi pembelajaran dan situasi kondisi lingkungan.

Di Madrasah Aliyah memiliki visi misi yang condong pada pendidikan akhlak dan budi pekerti yang sesuai dengan syariat Islam. Nilai religius banyak diterapkan di madrasah. Nilai religius merupakan nilai karakter dalam hubungannya dengan Tuhan. Ia menunjukkan bahwa pikiran, perkataan, dan tindakan seseorang yang diupayakan selalu berdasarkan pada nilai-nilai ketuhanan atau ajaran agamanya. $^{14}$

Nilai-nilai pendidikan karakter dapat melekat pada proses kegiatan pembelajaran mulai dari kegiatan awal, kegiatan inti, kegiatan penutup, dan dalam materi pembelajaran. Melekatnya nilai pendidikan karakter pada proses kegiatan dan materi pembelajaran, akan menjadi dasar pengembangan pengimplementasian nilai-nilai kepada peserta didik.

\section{Perencanaan Pembelajaran}

Implementasi pendidikan karakter pada kurikulum 2013, guru dituntut membuat RPP yang berkarakter dengan cara yang sederhana tapi mampu menghasilkan proses yang optimal dan hasil yang maksimal. Salah satu tugas guru dalam implementasi pendidikan karakter, guru harus merencanakan karakter yang akan dibentuk dalam pembelajaran. Pendidik (guru) diberikan kewenangan secara leluasa untuk mengembangkan RPP sesuai dengan kemampuan, karakter peserta didik dan kondisi lingkungan. Perencanaan pengajaran adalah suatu proses penyusunan alternatif kebijaksanaan mengatasi masalah-masalah yang akan dilaksanakan dalam rangka mencapai tujuan pembangunan pendidikan nasional dengan mempertimbangkan kenyataan-kenyataan yang ada dibidang sosial-ekonomi, sosial-budaya

${ }^{14}$ Mustari, Mohammad. (2014). Nilai Karakter Refleksi untuk pendidikan. Jakarta: PT. Rajagrafindo Persada. hal 1. 
dan kebutuhan pembangunan secara menyeluruh terhadap pendidikan nasional. ${ }^{15}$

Rencana Pelaksanaan Pembelajaran adalah kerangka atau rencana proses kegiatan yang terdiri dari kegiatan awal, kegiatan inti, dan kegiatan akhir, yang disusun untuk satu pertemuan atau lebih sesuai dengan situasi, kondisi peserta didik serta lingkungannya. Rencana pelaksanaan pembelajaran ini merupakan dasar dari pelaksanaan kegiatan pembelajaran. semua kegiatan yang akan dilaksanakan tertulis dalam RPP. Mulai dari Identitas, Kopetensi Inti (KI), Kopetensi Dasar (KD), indikator, tujuan, materi, metode, media, langkah-langkah kegiatan (kegiatan awal, inti, dan akhir), penilaian, dll.

\section{METODOLOGI PENELITIAN}

Penelitian ini merupakan penelitian deskriptif kualitatif, dimana penelitian ini menggunakan kata-kata sebagai cara untuk menjelaskan mengenai objek penelitian melalui langkah-langkah ilmiah dan selanjutnya dianalisis secara kualitatif dan dideskripsikan. Sumber data penelitian berupa RPP (materi aksara Jawa) yang disusun oleh guru Madrasah Aliyah Negeri 2 Kabupaten Boyolali. Data penelitian diperoleh dengan membaca secara cermat skenario pembelajaran aksara Jawa kemudian mengkaji kegiatankegiatan yang direncanakan guru serta kandungan nilai-nilai pendidikan karakter yang tercermin dalam kegiatan skenario pembelajaran. Hasil analisis selanjutnya dideskripsikan sedemikian rupa sehingga diketahui bagaimana pengintegrasian nilai religius dalam RPP.

Pendekatan studi kasus digunakan dalam penelitian ini karena dapat digunakan untuk menguraikan dan menjelaskan secara rinci mengenai berbagai aspek mengenai individu maupun kelompok, serta suatu program dan situasi sosial. Kasus ini dilakukan pada satu sasaran (satu program) sehingga penelitian ini digolongkan dalam kasus tunggal. Oleh sebab itu, studi kasus merupakan strategi penelitian yang dinilai relevan dengan penelitian yang dilakukan.

${ }^{15}$ Harjanto. (2003). Perencanaan Pengajaran. Jakarta: Rineka Cipta. hal 7.

\section{HASIL DAN PEMBAHASAN}

Rencana pembelajaran diibaratkan seperti peta yang dipakai sebagai petunjuk ataupun pedoman berlayar untuk menuju ke suatu tempat dengan mengacu pada suatu kompas. ${ }^{16}$ Jika RPP diibaratkan sebagai peta, kurikulum diibaratkan sebagai kompasnya. Berlayar dalam hal ini merupakan cerminan dari pelaksanakan pembelajaran yang akhirnya dapat mengantarkan peserta didik untuk dapat memahami materi serta mengaplikasikan dalam kehidupannya. Perencanaan pembelajaran merupakan proses penerjemahan kurikulum yang berlaku menjadi program-program pembelajaran yang dapat dijadikan sebagai pedoman bagi guru dalam penyelenggaraan proses pembelajaran. ${ }^{17}$

Melalui perencanaan pembelajaran inilah seorang pendidik dapat meramalkan bagaimana pembelajaran yang akan dilaksanakan serta bagaimana hasil yang akan didapatkan dalam mencapai tujuan dari pembelajaran.

Dalam penyusunan RPP format penulisan di setiap daerah memiliki gaya selingkung sendiri-sendiri, akan tetapi komponen yang ada di dalamnya tetap sesuai dengan komponen yang telah diatur. Berdasarkan pada lampiran Permendikbud no 81 a tahun 2013 tentang implementasi kurikulum, dapat diketahui bahwa kegiatan pelaksanaan pembelajaran tergambar pada bagian skenario pembelajaran. Mulai dari pertemuan pertama hingga pertemuan keempat (P1,P2, P3, dan P4). Pembuatan rencana pembelajaran dapat dikembangkan sendiri oleh guru berdasarkan kebutuhan peserta didiknya.

Dari analisis yang telah dilakukan oleh peneliti ditemukan adanya nilai pendidikan yang diintegrasikan di dalam skenario pembelajaran bahasa Jawa.

${ }^{16}$ Rumahlatu, Dominggus, et al. (2016). An Analysis of the readiness and implementation of 2013 Curriculum in the West Part of Seram Disrict, Maluku Province, Indonesia. Internasional Journal Of Environmental \& Science Education, 11(12), hal. 56625675 .

${ }^{17}$ Sanjaya, Wina. (2013). Perencanaan dan Desain Sistem Pembelajaran. Jakarta: Kencana Prenada Media Group. h 47. 


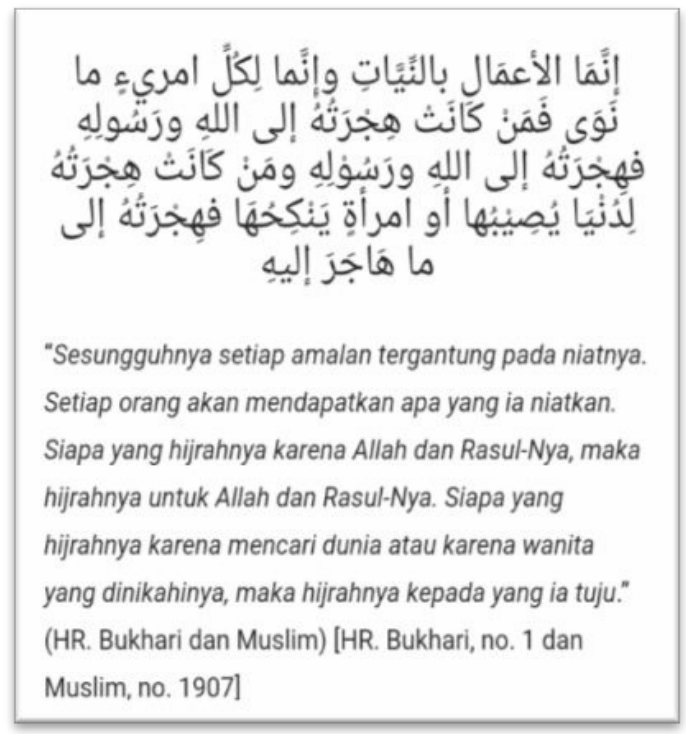

Gambar 1. Hadis dalam RPP Bahasa Jawa

Nilai religius atau nilai pendidikan karakter religius ditemukan dalam Rencana Pelaksanaan Pembelajaran (RPP) bahasa Jawa. Nilai religius adalah nilai karakter dalam hubungannya dengan tuhan, menunjukkan bahwa pikiran, perkataan, dan tindakan seseorang yang diupayakan selalu berdasarkan pada nilai-nilai ketuhanan dan atau ajaran agamanya. $^{18}$

Kegiatan yang berkaitan dengan agama dan kegiatan lain yang tujuannya hanya kepada Tuhan seperti berdoa, mengucap serta menjawab salam, dan hal-hal lainya yang terkandung dalam skenario pembelajaran akan dikelompokkan dalam analisis ini. Berikut merupakan cuplikan yang mengandung nilai religius dalam Rencana Pelaksanaan Pembelajaran (RPP).

"Guru mengucapkan salam, dilanjutkan dengan berdoa"( $\mathrm{P} 1, \mathrm{P} 2, \mathrm{P} 3, \mathrm{P} 4, \mathrm{Ka})$

"Memotivasi siswa melalui ayat atau hadis, dengan dikaitkan materi yang akan dipelajari” (P1, Ka).

"guru mengakhiri kegiatan pembelajaran dengan salam" (P1,2,3,4, Kp).

Kutipan di atas merupakan temuan dalam skenario pembelajaran yang mencerminkan

${ }^{18}$ Mustari, Mohamad. (2014). Nilai Karakter Refleksi untuk Pendidikan. Jakarta: PT. Raja grafindo Persada. h 1. nilai religius. Pada kegiatan awal baik pertemuan 1, 2, 3, 4 (P1, P2, P3, dan P4) ditemukan adanya nilai religius dengan kegiatan berdoa, mengucap salam serta menjawab salam, dan pertemuan 1 kegiatan awal (P1, Ka) terdapat motivasi yang dikaitkan dengan ayat Alquran atau hadis.

Pembiasaan mengucap salam ketika bertemu dengan orang lain merupakan salah satu kegiatan yang terpuji. Seorang muslim yang saling bertemu hendanya lebih baik mengucapkan salam 'Assalamu'alaikum' dan menjawabnya dengan 'wa'alaikumsalam' dengan begitu maka orang tersebut akan saling mendapatkan pahala dari Tuhan.

Salam yang lengkap yaitu
'Assalamu'alaikum warohmatullahi
wabarokatuh'. Ucapan salam mengandung pengertian doa dan harapan, 'Assalam' adalah salah satu dari sekian banyak Asma Allah dan karenannya 'Assalamu'alaikum' itu mengandung doa 'semoga kamu sekalian berada dalam pemeliharaan Allah' atau semoga keselamatan (dari) Allah akan selalu menyertaimu. Mengucap salam diperintahkan oleh agama dan hukumnya adalah sunnah; tetapi menjawab salam hukumnya wajib 'ain bagi yang sendirian dan wajib kifayah bila orang yang menerima salam tersebut jmlahnya lebih dari seorang. Menurut hadis yang diriwayatkan oleh H.R Muslim dan Abi Huraira r.a, Rosulullah bersabda "Hak seorang 
muslim terhadap orang Islam lainnya ada enam, satu diantaranya jika kamu jumpai seorang muslim, maka hendaklah mengucapkan salam (Assalamu'alaikum) kepadanya. $^{19}$

Berdasarkan hal tersebut, menjawab salam dalam agama Islam merupakan kewajiban, karena salam merupakan sebuah doa, sehingga orang yang mendengar seseorang mengucap salam wajib untuk menjawabnya.

Dalam kehidupan sehari-hari, manusia sering menghadapi kesulitan yang tidak dapat diselesaikan sendiri. Sebagai manusia yang beriman, selain berusaha jalan yang harus ditempuh adalah dengan berdoa. Berdoa artinya memohon kepada Allah sesuatu hajat (kebutuhan), baik kebutuhan lahir yang susah diperoleh maupun kebutuhan batin. Doa adalah fitrah manusia, karena kelemahannya. Dengan berdoa kita akan ingat selalu dengan Allah. Allah Yang Mahakuasa menolong manusia dalam kesulitan. Menurut ajaran Islam, berdoa merupakan pengabdian dan ibadah kepada Allah. Oleh karena itu, barang siapa yang berdoa akan mendapatkan pahala dan permohonannya akan dikabulkan oleh Allah. ${ }^{20}$

Kegiatan berdoa sebelum melaksanakan kegiatan merupakan cara atau pembiasaan baik yang dapat ditanamkan kepada peserta didik. Seperti kegiatan berdoa pada awal kegiatan pembelajaran. Doa sebelum belajar akan melatih siswa untuk membiasakan diri untuk berdoa untuk mengawali kegiatan-kegiatan lainnya. Kegiatan berdoa sebelum pelajaran akan memberikan manfaat yang baik bagi siswa jika dilaksanakan dengan ikhlas, dan menyerahkan segalanya kepada Tuhan atas apa yang diharapkan dari pelaksanaan pembelajara, insyaallah dalam mengikuti pembelajaran siswa akan diberikan kemudahan dalam menerima ilmu-ilmu yang baru dari pelajaraan

\footnotetext{
${ }^{19}$ Amin, dkk. (1998). Materi Pokok Quran-Hadis I. Departemen Agama Jakarta: direktorat Jendral Pembinaan Kelembagaan Agama Islam, Universitas terbuka. Hal 34 20

. 1998. Buku Pelajaran Agama Islam Aqidah Akhlak. Jakarta: Direktorat jendral Pembinaan Kelembagaan Agama Islam Departemen Agama RI. Hal 42-43.
}

yang diikuti. Karena pada dasarnya berdoa adalah permohonan kepada Tuhan.

Rencana Pelaksanaan Pembelajaran (RPP) dikembangkan guru madrasah pada bagian motivasi. Ditemukan adanya suatu ayat Alquran atau hadis yang berkaitan dengan niat, dan hadis tersebut diriwayatkan oleh Bukhari dan Muslim. Hadis tentang niat bisa dijadikan sebagai motivasi siswa bahwa diperlukan niat yang dalam untuk melakukan proses pembelajaran, oleh karena itu pada diri seorang siswa maupun guru/pendidik hendaknya tajdidunniyat untuk menuntut ilmu sematamata karena Allah dan dengan tujuan tertentu sesuai dengan cita-citanya. ${ }^{21}$

Hadis merupakan dasar hukum Islam yang kedua setelah Alquran. Hadis itu berada di posisi kedua setelah Alquran dengan konotasi bahwa rujukan hukum dan normanorma keagamaan yang utama adalah Alquran dan hadis dipergunakan sebagai bahan kajian untuk memahami pesan-pesan Alquran atau dirujuk setelah ternyata bahwa Alquran tidak memberikan paparan-paparan tekstual tentang persoalan-persoalan yang dihadapi. ${ }^{22}$

Sebagai sumber hukum Islam yang kedua sesudah Alquran, hadis tidak hanya dibaca tetapi juga harus dipahami kandungan maknanya, agar dapat dipedomani dan diterapkan dalam kehidupan sehari-hari sebagai setiap muslim. ${ }^{23}$

Hadis dalam RPP tersebut merupakan salah satu dalil yang menunjukkan pentingnya suatu niat dalam segala amal yang dilakukan agar bernilai pahala. Apabila seseorang dalam menjalankan suatu hal dengan diniatkan karena Allah maka apa yang dicita-citakan di dunia juga akan masuk di dalamnya, sehingga dengan begitu, kita akan mendapat pahala serta apa yang kita harapkan di dunia juga akan kita dapatkan.

\footnotetext{
${ }^{21}$ Rosidi, Ayep. (2017). "Niat Menurut Hadis da Implikasinya Terhadap Proses Pembelajaran". Jurnal Inspirasi, vol 1, No. 1, 49.

${ }^{22}$ Amin, dkk. (1996). Materi Pokok Quran Hadis II. Jakarta: Direktorat Jendral Pembinaan Kelembagaan agama Islam dan Universitas terbuka. Hal 262.

${ }^{23}$ Mukhtar, dkk. (1998). Materi Pokok Pendidikan Agama Islam. Jakarta: Direktorat Jendral Pembinaan Kelembagaan Agama Islam dan Universitas Terbuka. Hal 141.
} 
Terdapat tiga batasan minat yakni: (1) suatu sikap yang dapat meningkatkan perhatian seseorang kearah objek tertentu secara selektif, (2) suatu perasaan bahwa aktivitas dan kegemaran terhadap objek tertentu sangat berharga bagi individu, (3) bagian dari motivasi atau kesiapan yang membawa tingkah laku pada suatu arah atau tujuan tertentu. ${ }^{24}$

Niat seseorang dalam mengikuti kegiatan pembelajaran akan berpengaruh terhadap apa yang akan didapatkan. Jika seseorang telah berniat ingin belajar dengan sungguh-sungguh maka secara otomatis seseorang juga akan menanamkan sebuah minat dalam dirinya untuk belajar dengan sungguh-sungguh. Jika seseorang telah menaruh minat dalam dirinya terhadap suatu hal, maka perasaan senang, keingintahuan yang tinggi terhadap suatu hal tersebut akan dimiliki oleh seorang tersebut. Dengan begitu seseorang akan lebih menaruh perhatian lebih demi mengetahui informasi tentang apa yang ingin mereka ketahui terhadap hal tersebut.

Secara fungsional minat merupakan suatu jenis pengalaman, perasaan yang dianggap bermanfaat dan diasosiasikan dengan perhatian pada suatu objek tertentu. Secara struktural minat merupakan suatu elemen dalam diri individu, baik bawaan maupun yang diperoleh lewat proses belajar yang menyebabkan seseorang merasa mendapatkan manfaat, merasa berhubungan dengan suatu objek tertentu terhadap suatu pengetahuan tertentu. $^{25}$

Minat seseorang yang timbul tidak tumbuh begitu saja. Terkadang minat seseorang timbul karena adanya rangsangan yang diberikan oleh orang lain atau dirinya sendiri akibat adanya stimulus yang dihasilkan dari panca indra kita. Hasil dari suatu yang dilihat, didengar, dirasa, kemudian akan diterjemahkan oleh otak yang nantinya akan membentuk suatu keputusan berupa perasaan senang atau tidak senang terhadap suatu hal. Akibat dari adanya respon dari pancaindra

${ }^{24}$ Iskndarwassid, dan Sunendar, Dadang. (2003). Strategi Pembelajaran Bahasa. Bandung: PT Remaja Rosdakarya. Hal 114.

${ }^{25}$ Taufani, C. K. (2008). Menginstal Minat Baca Siswa. Bandung: PT Globalindo Universal Multikreasi. Hal 38. yaitu melihat mendengar atau merasa, kondisi tersebut dapat dimanfaatkan oleh guru untuk memberikan suatu motivasi yang dapat diterima oleh indra pendengar sehingga akan memunculkan minat siswa dalam mengikuti kegiatan belajar. Hal ini sesuai dengan penjelasan Zaini, dkk pada cara kerja otak bahwa proses pengolahan informasi diawali dengan adanya stimulus dari lingungan luar yang diterima melalui alat-alat indra dalam bentuk cahaya, gambar, bunyi, suhu, tekanan, dan lain-lain. Agar diproses melalui sistem pengolahan informasi, stimulus tersebut harus mendapat respons terarah (orienting respons), satu respon yang memfokuskan perhatian kita kepada stimulus tersebut. Respon terarah tersebut menumbuhkan minat dan membuat kita ingin lebih mengetahui stimulus tersebut. $^{26}$

Berdasarkan informasi dari guru bahasa Jawa di Madrasah Aliyah Negeri 2 Kabupaten Boyolali bahwa memang dari pihak madrasah mengharuskan dalam sebuah RPP mengintegrasikan suatu ayat Alquran ataupun hadis yang berkaitan dengan materi yang akan dipelajari. Pengintegrasian ayat Alquran atau hadis bisa dimasukan pada bagian apersepsi, ataupun dikaitkan langsung dengan materi yang dipelajari. Pengimplementasian hadis dalam RPP supaya nanti dalam pembelajaran guru juga menyampaikan beberapa hal yang berkaitan dengan agama yang dikaitkan pada materi pelajaran ataupun pembiasaan terhadap perilaku siswa, melalui kebiasaan mendengarkan hal-hal yang berkaitan dengan agama, sekolah berharap peserta didiknya memiliki akhlak yang baik. ${ }^{27}$

Tujuan guru bahasa Jawa adalah memberikan hadis tentang niat dalam materi aksara Jawa bukan tanpa tujuan. Akan tetapi, saya gunakan untuk memotivasi siswa terhadap materi aksara Jawa yang kebanyakan siswa tidak menaruh minat dengan aksara Jawa karena bagi siswa itu materi yang sulit. Dengan saya berikan motivasi yang saya kaitkan dengan materi aksara Jawa, harapan saya siswa menjadi termotivasi, sehingga siswa menaruh

${ }^{26}$ Zaini, Hisyam., dkk. (2002). Desain Pembelajaran Di Perguruan Tinggi. Yogyakarta: CTSD IAIN Sunan Kalijag Yogyakarta. Hal 117-118.

${ }^{27}$ Hasil wawancara dengan guru bahasa Jawa 
minat terhadap pelajaran ang akan mereka pelajari. ${ }^{28}$

Salah satu misi dari madrasah yaitu membiasakan perilaku mulia (akhlakulkarimah) di setiap aktivitas guna membentuk kader pembangunan yang berjiwa Islam. Melalui kegiatan pembelajaran yang dilaksanakan lembaga pendidikan Islam Madrasah Aliyah Negeri 2 Boyolali, mengharapkan misi tersebut dapat terwujud dengan memasukkan unsur-unsur agama, atau Islami dalam mata pelajaran lain selain dalam mata pelajaran agama.

Pengintegrasian unsur religius dalam skenario pembelajaran, apabila dalam pelaksanaan pembelajaran diterapkan sesuai dengan rencana yang telah dipersiapkan, maka unsur tersebut dapat menjadi bagian dari kegiatan belajar yang dilaksanakan secara berkesinambungan dan terus menerus. Hal tersebut akan menjadi suatu kebiasaan yang baik, terlebih untuk madrasah.

Pemberian unsur ayat atau hadis dalam sebuah Rencana Pelaksanaan Pembelajaran (RPP) merupakan terobosan yang positif bila diimplementasikan dalam pelaksnaan pembelajaran. Kegiatan tersebut menjadikan mata pelajaran bahasa Jawa dapat berkonstribusi dalam penanaman nilai pendidikan karakter nilai religius di lembaga pendidikan Islam.

\section{PENUTUP}

Berdasarkan analisis yang telah dilakukan didapatkan simpulan bahwa Rencana Pelaksanaan Pembelajaran bahasa Jawa pada siswa kelas X MAN 2 Boyolali mengandung unsur pendidikan karakter religius. Nilai religius diwujudkan pada kegiatan awal di setiap pertemuan dengan mengucap salam dan berdoa. Selain itu, ditemukan adanya potongan ayat Alquran atau hadis dalam RPP pada bagian motivasi.

Mata pelajaran bahasa Jawa dapat digunakan sebagai media penanaman nilai pendidikan karakter religius di lembaga pendidikan Islam. Internalisasi unsur keisalaman berupa nilai religius pada RPP bahasa Jawa dapat dimanfaatkan dalam implementasi pembelajaran bahasa Jawa, sehingga mata pelajaran bahasa Jawa dalam lembaga pendidikan Islam dapat berkonstribusi sebagai penanaman nilai pendidikan karakter religius kepada peserta didik.

\section{UCAPAN TERIMA KASIH}

Sebelumnya penulis ucapkan Alhamdulillah atas terselesaikannya artikel jurnal yang saya kirimkan di Jurnal Edukasi mengenai "Internalisasi Nilai Religius Pada Rencana Pelaksanaan Pembelajaran (RPP) Muatan Lokal Bahasa Jawa Di Lembaga Pendidikan Islam". Dalam penyusunan artikel ini tentunya penulis melibatkan beberapa pihak yang membantu dalam penyusunan artikel. Penulis juga menyampaikan ucapan terima kasih kepada Tuhan, kedua orang tua yang selalu mensuport memberikan semangat, dukungan, doa, biaya, serta kasih sayang yang luarbiasa. Kedua kepada pihak Madrasah baik dari kepala serta guru bahasa Jawa yang telah berkenan memberikan izin serta kesempatan, pelayanan, tanggapan kepada peneliti untuk mendapatkan data-data yang dibutuhkan dan yang terakhir kepada pihak jurnal Edukasi yang telah memilih artikel ini yang dinilai sesuai dengan jurnal Edukasi. Harapan penulis apabila artikel ini dipublikasikan, semoga artikel ini dapat memberikan manfaat bagi pembaca, serta dapat memberikan inspirasi kepada calon peneliti selanjutnya untuk melakukan penelitian lebih lanjut berkaitan dengan topik artikel ini.

\section{DAFTAR PUSTAKA}

Amin, dkk. (1998). Buku Pelajaran Agama Islam Aqidah Akhlak. Jakarta: Direktorat jendral Pembinaan Kelembagaan Agama Islam Departemen Agama RI.

Amin, dkk. (1996). Materi Pokok Quran Hadis II. Jakarta: Direktorat Jendral Pembinaan Kelembagaan Agama Islam dan Universitas Terbuka.

Amin, dkk. (1998). Materi Pokok Quran-Hadis I. Departemen Agama Jakarta: direktorat Jendral Pembinaan Kelembagaan Agama Islam, Universitas terbuka.

\footnotetext{
${ }^{28}$ Hasil wawancara dengan guru bahasa Jawa
} 
Damayanti, Deni. (2014). Panduan Implementasi Pendidikan Karakter Di Sekolah. Yogyakarta: Araska.

Faiqoh. (2015). "Model Pembentukan Karakter Religius Santri Tahfidz Al-Quran Di Pondok Pesantren Mathali'ul Huda Pusat Kajen Pati". Jurnal EDUKASI, Vol 13, No. 3, h 350.

Harjanto. (2003). Perencanaan Pengajaran. Jakarta: Rineka Cipta.

Hidayat, Faiq. (2018). "Viral Guru di-bully Murid, Sekolah Akan Perkuat Pendidikan Karakter". Detiknews. Diakses $19 \quad$ November 2018. https://news.detik.com/berita/4299012/vi ral-guru-di-bully-murid-sekolah-akanperkuat-pendidikan-karakter.

Kartika Sari, Fitrina., Suwandi, Sarwiji., dan Supana. (2018). "Caracter Education Values In Semiotic Meaning Of Story Of Javanese Script". Jurnal Komposisi. Vol 19, No. 1, hal 48-63.

Ma'rifataini, Lisa'diyah . (2017). "Best ractice Pendidikan Agama Isam (PAI) Di Sekolah (SMA/SMK). Jurnal EDUKASI: Jurnal Penelitian Pendidikan Agama dan Keagamaan. Vol 15, No. 1, h 35.

Mukhtar, dkk. (1998). Materi Pokok Pendidikan Agama Islam. Jakarta: Direktorat Jendral Pembinaan Kelembagaan Agama Islam dan Universitas Terbuka.

Mulyasa. (2012). Manajemen Pendidikan Karakter. Jakarta: Bumi Aksara.

Mustari, Mohamad. (2014). Nilai Karakter Refleksi untuk Pendidikan. Jakarta: PT. Raja grafindo Persada. h 1.

Mustari, Mohammad. (2014). Nilai Karakter Refleksi untuk pendidikan. Jakarta: PT. Rajagrafindo Persada.

Muzayanah, Umi. (2014). "Strategi Pendidikan Karakter Pada Madrasah Tsanawiyah Muhammadiyah 01 Purbalingga, Jawa Tengah”. Jurnal Edukasi, Vol. 12, No. 3., h 339-340.
Pemerintah Provinsi Jawa Tengah. Kurikulum 2013 Muatan Lokal Bahasa Jawa. Jawa Tengah: Dinas pendidikan Provinsi Jawa Tengah.

Permendikbud Nomor 81 a Tahun 2013 Tentang Implementasi Kurikulum.

Purwadi. 6 Februari 2018. "Siswa Bunuh Guru, Jokowi: Ada Apa ini? Kenapa ini Terjadi?". Republika.co.id. Diakses 20 Apri 2018.

Rosidi, Ayep. (2017). "Niat Menurut Hadis da Implikasinya Terhadap Proses Pembelajaran". Jurnal Inspirasi, vol 1, No. 1, 39-50.

Rumahlatu, Dominggus, et al. (2016). "An Analysis of the readiness and implementation of 2013 Curriculum in the West Part of Seram Disrict, Maluku Province, Indonesia". Internasional Journal of Environmental \& Science Education, Vol, 11. No. 12, hal 56625675.

Saddhono, Kundharu dan Kurniawan, alva. (2017). "Islamic Religious in Traditional ceremony of Begalan Banyumasan as Educational Character for Student at Senior High Schools In Central Java". Internasional Journal of Islamic and Civivilizationnal Studies. Vol 4, No. 1, 71-77.

Saddhono, Kundharu dan Pramestuti, Dewi. (2018). "Sekar Macapat Pocung: Study Of Religius Values Based On Javanese Local Wisdom". Jurnal El Harakah,Vol 20, No.1, 15-32.

Sanjaya, Wina. (2013). Perencanaan dan Desain Sistem Pembelajaran. Jakarta: Kencana Prenada Media Group.

Siswanta, Jaka. (2017). Pengembangan Karakter Kepribadian Anak Usia Dini (Studi Kasus PAUD Islam Terpaadu Di Kabupaten Magelang Tahun 2015). Jurnal Inferensi, Vol 11, (1)

Zaini, Hisyam., dkk. (2002). Desain Pembelajaran Di Perguruan Tinggi. Yogyakarta: CTSD IAIN Sunan Kalijag Yogyakarta. 